\title{
PENGARUH AKTIVITAS MENGHAFAL AL-QURAN TERHADAP KINERJA PEGAWAI (Studi Kasus Pada Rumah Tahfizh Darus Syifa' RSI Sultan Agung)
}

\author{
Samsudin, Toha Makhshun, Moh. Farhan \\ Fakultas Agama Islam Universitas Islam Sultan Agung Semarang
}

\begin{abstract}
One of the efforts made to build the performance of human resources management is to foster work motivation through the development of Human Resource s into qualified, professional and devoted personnel. Employee performance is very important in determining company performance. Sultan Agung Hospital is the first health service provider institution to organize the tahfizh al-Qur'an learning program for employees held at the House of Tahfizh Darus Syifa '. Preliminary study results at RSI Sultan Agung show that employees involved in memorizing the Koran have a good performance. This can be proven through the achievement of employee Key Performance Indicators (KPI), DP3 (List of Work Implementation Ratings) and work achievements. The approach used in this research is quantitative with experimental and survey methods. Data collection techniques were carried out through the collection of performance documents and questionnaires for 38 employees as samples of research objects. The analysis technique used is path analysis (descriptive and inferential statistical analysis).
\end{abstract}

Keywords : Tahfizh al-Quran, Employee Performance

\section{ABSTRAK}

Salah satu upaya yang dilakukan untuk membangun kinerja SDI adalah dengan menumbuhkan motivasi kerja melalui pengembangan SDI menjadi tenaga yang berkualitas, profesional dan bertaqwa. Kinerja pegawai sangatlah penting dalam menentukan performa perusahaan. RSI Sultan Agung merupakan lembaga penyelenggara jasa kesehatan pertama yang menyelenggarakan program pembelajaran tahfizh al-Quran kepada pegawai yang diselenggarakan di Rumah Tahfizh Darus Syifa'. Hasil studi pendahuluan pada RSI Sultan Agung menunjukkan pegawai yang terlibat dalam aktivitas menghafal al-Quran memiliki kinerja baik. Hal ini dapat dibuktikan melalui pencapaian Key Performance Indicator (KPI) pegawai, DP3 (Daftar Penilaian Pelaksanaan Pekerjaan) dan prestasi kerja yang diraih. Pendekatan yang digunakan dalam penelitian ini adalah kuantitatif dengan metode eksperimen dan survey. Teknik pengumpulan data dilakukan melalui pengumpulan dokumen-dokumen capaian kinerja serta angket terhadap 38 pegawai sebagai sampel objek penelitian. Teknik analisis yang digunakan adalah analisis jalur (path analysis) yaitu analisis statistik deskriptif dan inferensial.

Kata kunci : Tahfizh al-Quran, Kinerja Pegawai. 


\section{A. PENDAhULUAN}

Al-Qur'an telah menyatakan dirinya sebagai kitab petunjuk (hudan) yang dapat menuntun umat manusia menuju ke jalan yang benar. Selain itu, ia juga berfungsi sebagai pemberi penjelasan (tibyan) terhadap segala sesuatu dan pembeda (furqan) antara kebenaran dan kebatilan. Keindahan bahasa Al-Qur'an, kedalaman maknanya serta keragaman temanya, membuat pesan-pesannya tidak pernah berkurang, apalagi habis, meski telah dikaji dari berbagai aspeknya. Keagungan dan keajaibannya selalu muncul seiring dengan perkembangan akal manusia dari masa ke masa. Kandungannya seakan tak lekang disengat panas dan tak lapuk dimakan hujan. Karena itu, upaya menghadirkan pesan-pesan Al-Qur'an dan upaya memelihara otentisitasnya melalui aktivitas menghafal AlQur'an merupakan proses yang tidak pernah berakhir selama manusia hadir di muka bumi.

Pada saat Rasulullah masih hidup, spirit mempelajari Al-Quran yang ditunjukkan para sahabat demikian luar biasa, bahkan para salafus shaleh mengawali menuntut ilmu mulai dengan belajar dan menghafal Al-Qur'an, sehingga Islam telah berhasil mencetak banyak ulama yang mempunyai multidisiplin ilmu, dan bisamembangun dan memimpin dunia sehingga sampai dua belas abad lebih. Para sahabat dan salafus shaleh mereka sangat akrab sekali dengan al-Quran sampai-sampai ada yang mengkhatamkan membacanya dalam sebulan, seminggu, bahkan sampai tiga hari (Muhith, 2012: 74).
Keberhasilan para pendahulu saleh dalam menciptakan harmoni antara kehidupan material dengan kehidupan spiritual adalah karena mereka menjadikan akhirat sebagai tujuan akhir; mereka membaca kitab Allah, mendirikan shalat, menafkahkan sebagian dari yang telah Allah rezekikan kepada mereka, baik secara sembunyi atau terang-terangan. Mereka adalah para pialang akhirat (Riyadi, 2005: 12).

Pada kajian ilmiah, aktivitas membaca al-Quran diyakini memiliki pengaruh terhadap kejiwaan seseorang karena tubuh manusia bisa terpengaruh oleh suara, begitu juga bagian otak. Jadi ketika seseorang menghafal al-Qur"an, maka suara yang keluar akan sampai ke telinga kemudian sampai ke otak dengan getaran yang bisa memberikan pengaruh positif bagi sel-sel otak sebagaimana yang telah ditetapkan fitrahnya oleh Allah. Hal ini sebagaimana diterangkan dalam Al-Qur'an surat az-Zumar ayat 23:

"Allah telah menurunkan perkataan yang paling baik (yaitu) al-Quran yang serupa(mutuayat-ayatnya) lagi berulang-ulang, gemetar karenanya kulit orang-orang yang takut kepada Tuhannya, kemudian menjadi tenang kulitdan hatimerekadi waktu mengingat Allah.Itulah petunjuk Allah, dengan kitab itu Dia menunjuki siapa yang dikehendaki-Nya dan Barangsiapa yang disesatkan Allah, niscaya tak ada baginya seorang pemimpinpun”. (Q.S. AzZumar: 23). 
Berkaitan dengan ayat di atas, Abduldaem al-Kaheel dalam bukunya $\mathrm{Al}$ Qur'an the Healing Book mengatakan, "dalam ayat yang mulia ini kita menyaksikan bahwa kulit dan hati orang- orang yang beriman gemetar karena takut kepada Allah, kita akan menyaksikan bahwa Al-Quranul Karim memiliki pengaruh luar biasa terhadap tubuh, terutama sistem imunitas atau kekebalan tubuh. Kita akan bisa menegaskan bahwa membaca ayat-ayat Al-Qur'an bisa memperkuat tingkat kekebelan tubuh seseorang dan bahkan mampu mengembalikan keseimbangan gerak sistem sel, terutama sel otak dan jantung yang merupakan organ paling utama dalam tubuh manusia" (AL-Kaheel, 2010: 3).

Demikian halnya dengan aktivitas menghafal Al-Qur'an, menghafal AlQur'andapat mengontrol emosi penghafalnya karena hakikatnya Al-Qur'an dapat menenangkan hati. "Rasa tenang akan selalu menemani orang yang membaca Al-Qur'an". Ketika seorang hafidz dihadapkan dengan suatu masalah maka ia tidak akan mengeluh dan menyalahkan orang lain karena didalam hati dan jiwanya telah ada penawar. Ia telah mampu menguasai kecerdasan emosionalnya sehingga ia mampu melewati rintangan tersebut (Wahyudi dan Wahidi, 2016: 22).

RSI Sultan Agung adalah rumah sakit syariah pertama yang menyelenggarakan pembelajaran tahfizh Al-Quran bagi pegawainya. Proses pembelajaran tahfizh Al-
Quran dipusatkan di Rumah Tahfizh Darus Syifa' masjid Hamidun Kosim RSI Sultan Agung. Pembelajaran tahfizh sebenarnya telah berlangsung 5 tahun. Pada tahun 2018 program menghafal Al-Quran telah melahirkan 70 huffazh pegawai yang telah merampungkan hafalan juz 30. Dan pada tahun 2019, Rumah Tahfizh Darus-Syifa' telah mewisuda 52 huffazh, terdiri dari 30 hafizh juz 30 dan 22 hafizh juz 1. Untuk sebuah perusahaan yang bergerak di bidang jasa Pelayanan kesehatan, lahirnya para hafizh dalam jumlah yang tidak kecil dari kalangan pegawai tentu menjadi prestasi yang patut diapresiasi.

Berdasarkan hasil wawancara dan observasi, kehadiran para hafizh di RSI Sultan Agung memberikan dampak dan implikasi positif terhadap kinerja pegawai. Sebagaimana diketahui Salah satu faktor dalam organisasi yang harus mendapat perhatian pihak manajemen adalah kinerja pegawai. Kinerja suatu organisasi sangat dipengaruhi oleh kinerja pegawainya. Atau dapat dikatakan bahwa performa pegawai adalah perbandingan antara hasil dari suatu pekerjaan pegawai dengan pengorbanan yang telah dikeluarkan.

Hal ini sejalan dengan pandangan Islam bahwa kinerja bisa ditumbuhkan dengan membangun keyakinan yang benar, baik menyangkut hasil atau cara. "Dan katakanlah,"Bekerjalah kamu, maka Allah akan meliaht pekerjaanmu, begitu juga RasulNya dan orang-orang mukmin, dan kamu akan 
dikembalikan kepada (Allah) Yang Mengetahui yang ghaib dan yang nyata, lalu diberitakanNya kepada kamu apa yang Telah kamu kerjakan." (QS. At-Taubah: 105).

Ayat ini merupakan targhib (rangsangan/motivator) bagi mereka yang taat dan tarhib (ancaman) yang tidak taat. Seakan Allah berfirman, "Bekerjalah dengan sungguhsungguh demi masa depanmu, baik untuk dunia maupun akhirat, maka masing-masing memiliki konskuensi pahala (reward) maupun hukuman (punishment)." Jika di dunia perilakunya baik, maka ia akan mendapat pujian di dunia sekaligus pahala yang besar di akhirat.

Kinerja (performance) merupakan hasil kerja atau prestasi kerja. Kinerja mempunyai makna lebih luas, bukan hanya menyatakan sebagai hasil kerja, tetapi juga bagaimana proses kerja berlangsung. Kinerja adalah tentang melakukan pekerjaan dan hasil yang dicapai dari pekerjaan tersebut. Kinerja adalah tentang apa yang dikerjakan dan bagaimana cara mengerjakannya. Kinerja merupakan hasil pekerjaan yang mempunyai hubungan kuat dengan tujuan strategis organisasi, kepuasaan konsumen dan memberi kontribusi ekonomi (Wibowo, 2011:2).

Untuk melihat kinerja pegawai, RSI Sultan Agung menerapkan tolok ukur performa pegawai melalui Key Performance Indicator (KPI) dan penilaian DP3 yang dilakukan secara periodik. Hasil penilaian kinerja tersebut selanjutnya menjadi pertimbangan utama kenaikan karir, promosi serta status kepegawaian.

Untuk itu peneliti akan meneliti dengan objek penelitian pada pegawai peserta program pembelajaran tahfizh Al-Quran yang diselenggarakan di rumah tahfizh Darus Syifa agar mereka bisa melewati capaian kinerja yang ditetapkan oleh manajemen RSI Sultan Agung.

Berdasarkan latar belakang masalah penelitian di atas, maka peneliti merumuskan beberapa pertanyaan untuk mendalami permasalahan yang diteliti:

1. Bagaimana kinerja pegawai peserta program pembelajaran tahfizh di rumah tahfizh Darus Syifa' RSI Sultan Agung?

2. Bagaimanakah aktivitas menghafal al-Quran peserta program tahfizh di rumah tahfizh Darus Syifa' RSI Sultan Agung?

3. Adakah pengaruh aktivitas menghafal AlQur'an di rumah tahfizh Darus Syifa' terhadap kinerja pegawai RSI Sultan Agung?

\section{B. KEUTAMAAN MENGHAFAL AL- QURAN}

Menghafal Al-Qur'an merupakan aktivitas yang dapat dilakukan semua orang. Menghafal Al-Qur'an adalah salah satu cara untuk memelihara kemurnian Al-Quran. Oleh karena itu, beruntunglah bagi orang-orang yang dapat menjagaAl-Qur'an dengan cara menghafalkannya. Sedangkan Al-Qur'an sendiri adalah kalam Allah yang berfungsi 
sebagai petunjuk atau pedoman bagi ummat manusia. Untuk memahami isi kandungan AlQuran yaitu dengan cara menghafalkan dan mengamalkannya dalam kehidupan sehari-hari.

Seorang penghafal Al-Qur'an dituntut untuk memiliki kertertarikan yang tinggi terhadap Al-Qur'an, baik dalam proses menghafal maupun selesai menghafal. Salah satunya dengan mengetahui keutamaan dan hikmah dalam membaca dam menghafal AlQuran.

Diantara keutamaan menghafal al-Quran sebagaimana dirangkum oleh Ahsin W. Al-Hafidz, ada beberapa alasan mengapa menghafal al-Qur'an dianggap sangat penting dilakukan, yakni sebagai berikut. Pertama, al-Quran diturunkan dan diterima Nabi secara hafalan kemudian diajarkannya kepada sahabat pun dengan hafalan. Kedua, hikmah diturunkannya al-Qur'an secara berangsur- angsur mengisyaratkan motivasi dan semangat untuk menjaganya melalui hafalan dan memahami kandungannya dengan baik. Ketiga, firman Allah dalam Q.S. al-Hijr: 9 bersifat aplikatif, yang berarti bahwa jaminan terpeliharanya kemurnian al-Qur'an adalah Allah yang memberikannya, akan tetapi tugas operasional secara nyata harus dilakukan oleh umat yang memilikinya, yakni umat Islam. Keempat, menghafal al- Qur'an mempunyai hukum fardhu kifayah, yang artinya bahwa orang yang menghafal al-Qur'an tidak boleh kurang dari jumlah mutawatir sehingga tidak akan terjadi kemungkinan pemalsuan, pengurangan atau penambahan terhadap ayat-ayat
al-Qur'an. Jika kewajiban tersebut sudah terpenuhi, maka gugurlah kewajiban bagi yang lainnya. Adapun jika tidak terpenuhi, maka umat Islam seluruhnya akan menanggung dosa (Al- Hafidz, 2005: 22-25).

Bagi Rasulullah membaca dan menghafal Al-Qur'an bermanfaat untuk meneguhkan hati, menguatkan hati dan jiwa, juga membimbing dan membina umat Islam dalam menjalankan syariat Islam, untuk memberi jawaban dan respon atas permasalahan yang terjadi pada individu. Al-Quran mengandung keberkahan bagi siapa saja yang mengambilnya. Setiap kali kebaikan bertambah, maka keburukan akan berkurang. Setelah kebaikan bertambah, urusanurusan kita akan diberkahi Allah sesuai dengan harapan kita (Al-Dabisi, 2019: 28).

\section{Kinerja Pegawai}

Dalam Kamus Besar Bahasa Indonesia seperti yang dikutip oleh Hadari Nawawi dikatakan bahwa kinerja adalah suatu yang dicapai, prestasi yang diperlihatkan, kemampuan kerja. Sedang Lavasque mengatakan kinerja adalah segala sesuatu yang dikerjakan seseorang dan hasilnya dalam melaksanakan fungsi suatu pekerjaan. Dari dua pengertian tersebut terlihat bahwa kinerja bermakna kemampuan kerja dan hasil atau prestasi yang dicapai dalam melaksanakan suatu pekerjaan. (Nawawi, th: 62).

Menurut Moeheriono pengertian kinerja atau Performance merupakan gambaran mengenai tingkat pencapaian pelaksanaan suatu 
program kegiatan atau kebijakan dalam mewujudkan sasaran, tujuan, visi, dan misi organisasi yang dituangkan melaui perencanaan strategis suatu organisasi. Kinerja dapat diketahui dan di ukur jika individu atau sekelompok karyawan telah mempunyai kriteria atau atau standar keberhasilan tolak ukur yang ditetapkan oleh organisasi (Moeheriono, 2012: 95).

Menurut Bernadin dan Russel, seperti yang dikutip oleh Ahamad S. Ruky, sebagai yang dikutip oleh Abu Fahim Dkk, kinerja atau prestasi adalah catatan tentang hasil-hasil yang diperoleh dari fungsi-fungsi pekerjaan tertentu atau kegiatan tertentu selama kurun waktu tertentu. Menurut Soeprihanto, kinerja atau prestasi kerja adalah hasil kerja seorang karyawan selama periode tertentu, misalnya standar, target, sasaran, atau kriteria yang telah ditentukan terlebih dahulu dan disepakati bersama. (Fahmi et.all, 2014: 179).

Kinerja diukur dengan instrumen yang dikembangkan dalam studi yang tergabung dalam ukuran kinerja secara umum, kemudian diterjemahkan ke Dalam penilaian perilaku secara mendasar, meliputi: a) Kuantitas kerja, yaitu jumlah kerja yang dilakukan dalam suatu periode. b) Kualitas kerja, yaitu kualitas kerja yang dicapai berdasarkan syarat-syarat kesesuaian dan kesiapannya. c) Pengetahuan tentang pekerjaan, yaitu luasnya pengetahuan mengenai dan ketrampilan. d) Pendapat atau pernyataan yang disampaikan, yaitu keaktifan menyampaikan pendapat di dalam rapat. e)
Perencanaan kerja, yaitu kegiatan yang dirancang sebelum melaksanakan aktifitas pekerjaannya. Seperti firman Allah SWT sebagai berikut: dan Katakanlah: "Bekerjalah kamu, Maka Allah dan Rasul-Nya serta orangorang mukmin akan melihat pekerjaanmu itu, dan kamu akan dikembalikan kepada (Allah) yang mengetahui akan yang ghaib dan yang nyata, lalu diberitakan-Nya kepada kamu apa yang telah kamu kerjakan. (QS. At-Taubah:105) Penilaian kerja adalah proses yang dilakukan organisasi untuk mengevaluasi atau menilai keberhasilan karyawan dalam melaksanakan tugasnya. Penilaian dapat dilakukan dengan membandingkan hasil kerja yang dicapai karyawan dengan standar pekerjaan (Bangun, 2012: 231).

\section{METODE PENELITIAN}

\section{Desain Penelitian}

Jenis penelitian ini menggunakan metode kuantitatif. Metode kuantitatif dinamakan metode tradisional, karena metode ini sudah cukup lama digunakan sehingga sudah mentradisi sebagai metode untuk penelitian. Metode ini disebut sebagai metode positivistik karena berlandaskan pada pada filsafat positivisme. Metode ini sebagai metode ilmiah/scientic karena telah memenuhi kaidah-kaidah ilmiah yaitu konkrit/empiris, obyektif, terukur, rasional, dan sistematis. Metode ini juga disebut discovery karena dengan metode ini dapat ditemukan dan dikembangkan berbagai iptek baru.

Metode ini disebut metode kuantitatif 
karena data penelitian berupa angka-angka dan analisis menggunakan statistic (Sugiono, 2009: 7). Peneliti melakukan penelitian kepada sejumlah subjek dan objek penelitian, yaitu para pegawai peserta program pembelajaran tahfizh AlQuranyang berjumlah 30 pegawai. Seluruh populasi dijadikan objek penelitian mengingat jumlah objek yang diteliti tidak terlalu banyak. Teknik pengumpulan data menggunakan konsep Sugiyono, yaitu melalui teknik dokumentasi, observasi dan kuesioner (angket) dan gabungan ketiganya (Sugiono, 2009: 137).

Dalam menganalisis data digunakan Teknik pengumpulan dokumen-dokumen capaian kinerja pegawai dan skoring berdasarkan kuisioner yang diajukan kepada responden berdasarkan skala model Likert yang berisi sejumlah pertanyaan yang menyatakan objek yang hendak diungkap. Penskoran atas kuesioner menggunakan skala model Likert.

Dalam penelitian ini, untuk mengetahui ada tidaknya pengaruh aktivitas menghafal Al-Qur'an terhadap kinerja pegawai, maka pengolahan data penelitian ini menggunakan analisis perbandingan penilaian kinerja pegawai sebelum dan sesudah mengikuti program tahfizh melalui uji normalitas dan paired sampel $\mathrm{T}$ test, dilanjutkan dengan melakukan tabulasi data, diolah dengan rumus statistik dan dilakukan analisis.

Selanjutnya peneliti melakukan interpretasi data yaitu dengan angka indek korelasi yang dijadikan patokan untuk mengetahui besar kecilnya kekuatan korelasi ataupun pengaruh (kuat, lemah, atau tidak ada) diantara variabel yang diteliti. Dalam masalah ini ada dua macam cara dapat ditempuh, yaitu; 1) Interpretasi secara sederhana, dan 2) Interpretasi dengan menggunakan nilai Kolmogorov-Smirnov Test.

Adapun yang maksud interpretasi secara sederhana yaitu melihat tingkat keeratan korelasi atau korelasi atau pengaruh antar variabel dapat dilhat dari angka koefisien korelasi yang disajikan dalam bentuk tabel interprestasi koefisien korelasi.

\section{Waktu dan Tempat Penelitian}

Lokasi penelitian ini dilaksanakan di Rumah Tahfizh Darus Syifa’ RSI Sultan Agung yang merupakan tempat pembelajaran bagi para peserta program pembelajaran tahfizh AlQur'an, tepatnya berada di Jalan Raya Kaligawe km. 4 Semarang. Adapun waktu penelitian ini dilaksanakan dari bulan Juli hingga September 2019. Peneliti secara intensif melakukan penelitian di lembaga ini dimana lokasinya terintegrasi dengan area kampus Unissula dan RSI Sultan Agung. Rumah tahfizh Darus Syifa' dipilih sebagai obyek penelitian dengan alasan: merupakan rumah tahfizh pertama yang diselenggarakan oleh institusi rumah sakit di Indonesia.

\section{Populasi dan Responden}

Populasi dan responden dalam penelitian ini melibatkan peserta program tahfizh dan pejabat structural RSI Sultan Agung yang 
membidangi kepegawaian dalam wawancara. Pada tahun 2019 Rumah Tahfizh Darus Syifa' telah mewisuda 52 orang hafizh, terdiri dari jajaran Direksi, Manajer, Kepala Bagian, dan staf pelaksana. Terdapat 38 peserta program tahfizh yang akan dilakukan wawancara. Sedangkan untuk informan kunci dalam penelitian ini adalah:

1. Manajer Sumber Daya Insani

2. Kepala Bagian Personalia

3. Kepala Rumah Tahfzh Darus Syifa'

\section{Sumber Data}

Sumber data yang digunakan dalam penelitian adalah:

1. Data primer, yang meliputi:

a. Data berupa capaian kinerja pegawai tahun 2019 yang terdiri dari KPI (Key Performance Indicator), DP3 (Daftar Penilaian Pelaksanaan Pekerjaan) dan prestasi kerja atau penghargaan yang diraih.

b. Hasil wawancara yang diperoleh dari peserta program tahfizh Quran, serta ditambah wawancara dengan informan kunci yang menjalankan aktivitas menghafal al-Quran.

c. Hasil observasi lapangan.

2. Data sekunder yaitu data-data bersumber dari laporan-laporan atau dokumendokumen yang terkait.

\section{Teknik Pengumpulan Data}

Penelitian ini menggunakan teknik pengumpulan data:

1. Dokumentasi, yaitu pengumpulan data yang berasal dari sumber primer berupa dokumen-dokumen capaian kinerja pegawai

2. Wawancara mendalam, yaitu pengumpulan data dengan melakukan wawancara mendalam terhadap informan kunci.

3. Observasi, yaitu pengumpulan data dengan mengamati proses pembelajaran tahfizh Quran yang diikuti oleh peserta program tahfizh dengan bimbingan ustadz/ustadzah tahfizh.

4. Wawancara terstruktur, yaitu pengumpulan data dengan menggunakan instrument kuisioner.

\section{Analisis Data}

Setelah data terkumpul dari hasil pengumpulan data, peneliti akan melakukan pengolahan data. Secara garis besar, berikut ini langkah dalam analisis data: (1) Persiapan, (2) Tabulasi data, (3) Analisis data.

Sumber data pokok pada penelitian ini terdapat pada data penilaian KPI dan DP3. Untuk mengetahui adanya perbedaan dan pengaruh aktivitas menghafal al-Quran terhadap kinerja, maka data penilaian KPI dan DP3 sebelum dan sesudah mengikuti aktivitas menghafal al-Quran perlu dipasangkan. Oleh 
karena itu perlu metode uji banding dengan menggunakan paired sampel $\mathrm{T}$ Test. Dalam uji $\mathrm{T}$ berpasangan terdapat asumsi yang harus dipenuhi yaitu uji normalitas. Uji normalitas merupakan uji asumsi atau uji prasyarat dalam uji T berpasangan. Uji normalitas ini digunakan untuk mengetahui apakah data berdistribusi normal atau sebaliknya.

\section{HASIL PENELITIAN}

Penelitian ini bertujuan untuk menemukan pengaruh aktivitas menghafal alQuran terhadap kinerja pegawai sebelum dan sesudah mengikuti program tahfizh. Untuk mengetahui pengaruh aktivitas menghafal alQuran terhadap kinerja pegawai perlu melihat capaian kinerja KPI dan DP3 dengan membandingkan capaian sebelum dan sesudah mengikuti program tahfizh.

Metode yang digunakan dalam membandingkan data capaian kinerja adalah dengan uji paired sampel $\mathrm{T}$ Test atau uji $\mathrm{T}$ berpasang. Dalam uji T berpasangan terdapat asumsi yang harus dipenuhi yaitu uji normalitas. Uji normalitas merupakan uji asumsi atau uji prasyarat untuk mengetahui apakah data berdistribusi atau tidak.

\section{Uji Normalitas}

Berdasarkan hasil uji normalitas, berikut ini hasil perbandingan nilai KPI dan DP3 tahun 2018 dan nilai KPI dan DP3 tahun 2019:

- Hipotesis

$H_{0}$ : Data berdistribusi normal

$H_{1}$ : Data tidak berdistribusi normal

- Taraf Signifikansi $(\alpha=5 \%=0,05)$

- Statistik Uji

Menggunakan nilai Sig

- Kriteria Uji

Terima $H_{0}$ jika nilai Sig. $>\alpha$

- Interpretasi 
Tabel 1

Hasil Uji Normalitas

One-Sample Kolmogorov-Smirnov Test

\begin{tabular}{|ll|r|r|r|r|}
\hline & & $\begin{array}{r}\text { Nilai } \\
\text { KPI } \\
\text { sebelum }\end{array}$ & $\begin{array}{r}\text { Nilai DP3 } \\
\text { sebelum }\end{array}$ & $\begin{array}{r}\text { Nilai KPI } \\
\text { sesudah }\end{array}$ & $\begin{array}{c}\text { Nilai DP3 } \\
\text { sesudah }\end{array}$ \\
\hline $\mathrm{N}$ & & 38 & 38 & 38 & 38 \\
Normal Parameters $\mathrm{a}$, & Mean & 88.34 & 86.37 & 90.29 & 86.61 \\
& Std. Deviation & 4.238 & 3.795 & 4.649 & 4.017 \\
& Absolute & .205 & .118 & .220 & .155 \\
Most Extreme Differences & Positive & .136 & .118 & .110 & .155 \\
& Negative & -.205 & -.096 & -.220 & -.095 \\
Kolmogorov-Smirnov Z & & 1.263 & .725 & 1.356 & .957 \\
Asymp. Sig. (2-tailed) & & .083 & .669 & .050 & .319 \\
\hline
\end{tabular}

a. Test distribution is Normal.

b. Calculated from data.

Berdasarkan output uji normalitas didapat nilai sig untuk semua nilai KPI dan DP3 lebih dari 0,05 maka dapat disimpulkan bahwa data berdistribusi normal. Oleh karena itu asumsi data normalitas terpenuhi.

\section{Uji Paired T Test}

Setelah dilakukan uji Paired $\mathrm{T}$ test nilai KPI 2018 sebelum mengikuti program tahfizh dengan KPI 2019 setelah mengikuti program tahfizh, ditemukan hasil berikut ini:
- Hipotesis

$H_{0}$ : Tidak ada perbedaan nilai KPI sebelum (2018) dengan nilai KPI sesudah (2019)

$H_{1}$ : Ada perbedaan nilai KPI sebelum (2018) dengan nilai KPI sesudah (2019)

- Taraf Signifikansi $(\alpha=5 \%=0,05)$

- Statistik Uji Menggunakan nilai Sig

- Kriteria Uji Terima $H_{0}$ jika nilai Sig. $>\alpha$

- Interpretasi 
Tabel 2

Hasil Uji Paired T Test KPI

Paired Samples Test

\begin{tabular}{|c|c|c|c|c|c|c|c|c|c|}
\hline & & & Paire & Differe & nces & & $\mathrm{t}$ & $\mathrm{df}$ & Sig. (2- \\
\hline & & Mean & $\begin{array}{c}\text { Std. } \\
\text { Deviation }\end{array}$ & $\begin{array}{l}\text { Std. } \\
\text { Error } \\
\text { Mean }\end{array}$ & $\begin{array}{r}95 \% \text { Cor } \\
\text { Interval } \\
\text { Diffe }\end{array}$ & $\begin{array}{l}\text { fidence } \\
\text { of the } \\
\text { ence }\end{array}$ & & & tailed) \\
\hline & & & & & Lower & Upper & & & \\
\hline Pair 1 & $\begin{array}{l}\text { Nilai KPI } \\
\text { sebelum - } \\
\text { Nilai KPI } \\
\text { sesudah }\end{array}$ & $\begin{array}{r}- \\
1.947\end{array}$ & 1.229 & .199 & -2.351 & -1.543 & -9.767 & 37 & .000 \\
\hline
\end{tabular}

Berdasarkan output uji paired sampel $\mathrm{T}$ test didapat nilai sig. $0,000<0,05$ yang berarti $H_{0}$ ditolak. Jadi dapat disimpulkan bahwa ada perbedaan yang signifikan antara nilai KPI sebelum (2018) dengan nilai KPI sesudah (2019). Untuk melihat mana yang terbaik dapat dilihat dari tabel berikut:

Tabel 3

Hasil Uji Paired Samles Satatistic

Paired Samples Statistics

\begin{tabular}{|rr|r|r|r|r|}
\hline & \multicolumn{1}{|c|}{ Mean } & N & Std. Deviation & \multicolumn{1}{|c|}{ Std. Error Mean } \\
\hline \multirow{2}{*}{ Pair 1 } & Nilai KPI sebelum & 88.34 & 38 & 4.238 & .687 \\
& Nilai KPI sesudah & 90.29 & 38 & 4.649 & .754 \\
\hline
\end{tabular}

Hasil penelitian menunjukan bahwa nilai kinerja KPI (Key Performance Indikator) pegawai RSI Sultan Agung, sebelum mengikuti program tahfizh didapati nilai keseluruhannya adalah 4.238. Jika dirataratakan dengan cara dibagi sesuai dengan jumlah pegawai sebanyak 38 responden maka nilai rata-ratanya adalah $\mathbf{8 8 , 3 4}$. Sedangkan Jurnal Al-Fikri Volume 3 Nomor 1 - Februari 2020 
nilai kinerja KPI (Key Performance Indicator) pegawai RSI Sultan Agung, setelah mengikuti program tahfizh didapati nilai keseluruhannya adalah 4.649. Jika dirata-ratakan dengan cara dibagi sesuai dengan jumlah pegawai sebanyak 38 responden maka nilai rataratanya adalah 90,29. Ini berarti menunjukkan adanya kenaikan nilai KPI sebelum dan sesudah program Tahfizh. Selain itu hasil KPI menunjukan bahwa kinerja pegawai sangat baik. Hal ini mengacu pada ketentuan penilaian KPI RSI Sultan Agung sebagai berikut:

Tabel 4 - Ketentuan Penilaian KPI

\begin{tabular}{|l|l|l|}
\hline \multicolumn{1}{|c|}{ Skor Akhir } & Simbol Warna & \multicolumn{1}{c|}{ Deskripai Penilaian } \\
\hline$<60$ & & Kurang (Perlu Melakukan Perbaikan) \\
\hline $60,1-<75$ & & Sedang (Perlu adanya Perbaikan) \\
\hline $75,1-<90$ & & Baik (dan untuk ditingkatkan lagi) \\
\hline$\geq 90$ & & Sangat Baik (Dipertahankan) \\
\hline
\end{tabular}

Sedangkan uji Paired T test nilai DP3 tahun 2018 sebelum mengikuti program tahfizh dengan DP3 tahun 2019 setelah mengikuti program tahfizh, ditemukan hasil berikut ini:

- Hipotesis

$H_{0}$ : Tidak ada perbedaan nilai DP3 sebelum (2018) dengan nilai DP3 sesudah (2019)
$H_{1}$ : Ada perbedaan nilai DP3 sebelum (2018) dengan nilai DP3 sesudah (2019)

- Taraf Signifikansi $(\alpha=5 \%=0,05)$

- Statistik Uji Menggunakan nilai Sig

- Kriteria Uji Terima $H_{0}$ jika nilai Sig. $>\alpha$

- Interpretasi

Tabel 5 - Hasil Paired T Test DP3

Paired Samples Test

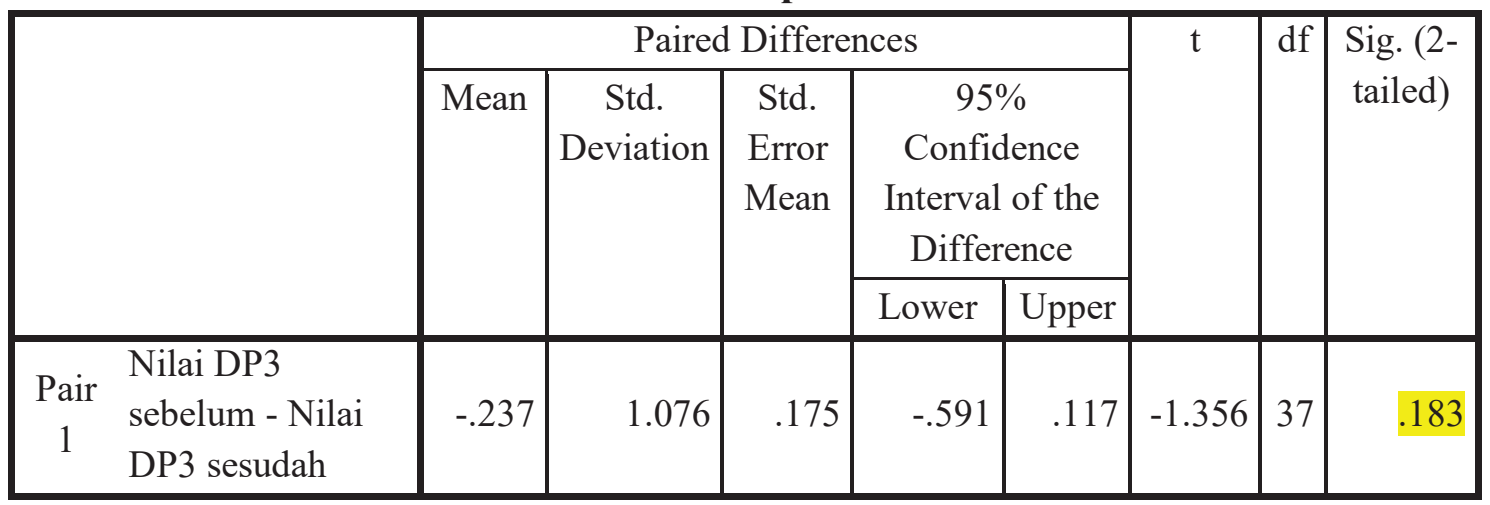


Berdasarkan output uji paired didapat nilai sig $0,183>0,05$ yang berarti $H_{0}$ diterima. Jadi dapat disimpulkan bahwa tidak ada perbedaan yang signifikan antara nilai DP3 sebelum (2018) dengan nilai DP3 sesudah (2019).

Tabel 6

Hasil Uji Paired Samples Statistic

Paired Samples Statistics

\begin{tabular}{|rr|r|r|r|r|}
\hline & \multicolumn{1}{|c|}{ Mean } & \multicolumn{1}{c|}{ N } & Std. Deviation & \multicolumn{1}{|c|}{ Std. Error Mean } \\
\hline \multirow{2}{*}{ Pair 1 } & Nilai DP3 sebelum & 86.37 & 38 & 3.795 & .616 \\
& Nilai DP3 sesudah & 86.61 & 38 & 4.017 & .652 \\
\hline
\end{tabular}

Tabel 7

Hasil penelitian menunjukan bahwa nilai kinerja DP3 pegawai RSI Sultan Agung, sebelum mengikuti program tahfizh didapati nilai keseluruhannya adalah 3.795. Jika dirataratakan dengan cara dibagi sesuai dengan jumlah pegawai sebanyak 38 responden maka nilai rata-ratanya adalah 86,37. Sedangkan nilai kinerja DP3 pegawai RSI Sultan Agung, setelah mengikuti program tahfizh didapati nilai keseluruhannya adalah 4.017. Jika dirataratakan dengan cara dibagi sesuai dengan jumlah pegawai sebanyak 38 responden maka nilai rata-ratanya adalah 86.61. Ini berarti menunjukkan adanya kenaikan nilai KPI sebelum dan sesudah program Tahfizh. Selain itu hasil KPI menunjukan bahwa kinerja pegawai baik. Hal ini mengacu pada ketentuan penilaian KPI RSI Sultan Agung sebagai berikut:
Ketentuan Penilaian DP3

\begin{tabular}{|l|c|}
\hline \multicolumn{1}{|c|}{ Skor Akhir } & Deskripai Penilaian \\
\hline $51-<60$ & Kurang \\
\hline $61-<75$ & Sedang \\
\hline $76-<90$ & Baik \\
\hline$\geq 91$ & Sangat Baik \\
\hline
\end{tabular}

Aktivitas menghafal al-Quran yang dilakukan adalah dengan cara menghafal dengan menggunakan metode al-Huffaz yaitu menghafal al-Quran secara bersama-sama dengan bimbingan seorang ustadz dan ustadzah. Target hafalan yang ditetapkan adalah one day one colour. Sebelum melanjutkan hafalan berikutnya, mereka memuroja'ah (mengulang) hafalan yang telah dihafal agar lebih kuat lagi. 
Pelaksanaan pembelajaran tahfizh alQuran diatur waktunya agar tidak berbenturan dengan aktivitas kerja yaitu pada pagi hari sebelum masuk kerja yaitu jam 07.00 - 08.00, setelah selesai sholat Zhuhur pada jam 12.15 13.00 dan setelah shalat Ashar pada jam 15.30 - 16.30 Setap hari Senin - Jumat. Kesungguhan mengikuti program tahfizh ini menunjukan adanya ghirah (semangat) pegawai dalam menghafal al-Quran di Rumah Tahfizh Darus-Syifa' sekaligus menunjukan adanya kemampuan menghafal al-Quran yang baik. Temuan ini dapat dilihat pada tabel di bawah ini:

Tabel 8

\section{Data Hafalan}

Pegawai

\begin{tabular}{|c|c|c|}
\hline No & $\begin{array}{c}\text { Nama Inisial } \\
\text { Responden }\end{array}$ & $\begin{array}{c}\text { Jumlah } \\
\text { Hafalan }\end{array}$ \\
\hline 1 & M.AM & $2 \mathrm{Juz}$ \\
\hline 2 & M.I & $2 \mathrm{juz}$ \\
\hline 3 & M.F & $1 \mathrm{juz}$ \\
\hline 4 & M & $1 \mathrm{Juz}$ \\
\hline 5 & FSA & 1 Juz \\
\hline 6 & RWN & 1 Juz \\
\hline 7 & SS & 2 Juz \\
\hline 8 & KK & 2 Juz \\
\hline 9 & MCM & 2 Juz \\
\hline 10 & AA & 1 Juz \\
\hline 11 & SMU & 1 Juz \\
\hline 12 & M.A.R & 2 juz \\
\hline
\end{tabular}

\begin{tabular}{|c|c|c|}
\hline 13 & A.S & 2 juz \\
\hline 14 & S.A & 2 juz \\
\hline 15 & W.U & $2 \mathrm{juz}$ \\
\hline 16 & D.A & 2 juz \\
\hline 17 & S.N & $2 \mathrm{juz}$ \\
\hline 18 & N.H & $2 \mathrm{juz}$ \\
\hline 19 & $\mathrm{~S}$ & 2 juz \\
\hline 20 & S.M & $1 \mathrm{juz}$ \\
\hline 21 & M.S & $1 \mathrm{juz}$ \\
\hline 22 & D.A & $1 \mathrm{juz}$ \\
\hline 23 & S.N.A & $1 \mathrm{juz}$ \\
\hline 24 & M.M & $1 \mathrm{juz}$ \\
\hline 25 & T.B.W & $1 \mathrm{juz}$ \\
\hline 26 & S.K & $1 \mathrm{juz}$ \\
\hline 27 & I.K & $1 \mathrm{juz}$ \\
\hline 28 & I & $1 \mathrm{juz}$ \\
\hline 29 & N.M.D & $1 \mathrm{juz}$ \\
\hline 30 & I.M & $1 \mathrm{juz}$ \\
\hline 31 & F.M & $1 \mathrm{juz}$ \\
\hline 32 & E.Y & $1 \mathrm{juz}$ \\
\hline 33 & L.M & $1 \mathrm{juz}$ \\
\hline 34 & R.A & $1 \mathrm{juz}$ \\
\hline 35 & $\mathrm{D}$ & $1 \mathrm{juz}$ \\
\hline 36 & D.A & $1 \mathrm{juz}$ \\
\hline 37 & N.K & $1 \mathrm{juz}$ \\
\hline 38 & $\mathrm{M}$ & $1 \mathrm{juz}$ \\
\hline
\end{tabular}


Tabel 9

Nilai Kinerja KPI dan DP3 Pegawai 2019

\begin{tabular}{|c|c|c|c|}
\hline No & $\begin{array}{c}\text { Nama } \\
\text { Inisial } \\
\text { Responden }\end{array}$ & $\begin{array}{l}\text { Nilai } \\
\text { KPI }\end{array}$ & $\begin{array}{l}\text { Nilai } \\
\text { DP3 }\end{array}$ \\
\hline 1 & M.AM & 93 & 93 \\
\hline 2 & M.I & 93 & 93 \\
\hline 3 & M.F & 93 & 93 \\
\hline 4 & $\mathrm{M}$ & 87 & 87 \\
\hline 5 & FSA & 82 & 82 \\
\hline 6 & RWN & 87 & 87 \\
\hline 7 & SS & 87 & 87 \\
\hline 8 & KK & 86 & 86 \\
\hline 9 & $\mathrm{MCM}$ & 85 & 85 \\
\hline 10 & AA & 88 & 88 \\
\hline 11 & SMU & 87 & 87 \\
\hline 12 & M.A.R & 91 & 87 \\
\hline 13 & A.S & 96 & 87 \\
\hline 14 & S.A & 95 & 87 \\
\hline 15 & W.U & 94 & 84 \\
\hline 16 & D.A & 94 & 82 \\
\hline 17 & S.N & 84 & 83 \\
\hline 18 & N.H & 76 & 92 \\
\hline 19 & $\mathrm{~S}$ & 96 & 89 \\
\hline 20 & S.M & 95 & 90 \\
\hline 21 & M.S & 94 & 83 \\
\hline
\end{tabular}

\begin{tabular}{|c|c|c|c|}
\hline 22 & D.A & 93 & 86 \\
\hline 23 & S.N.A & 93 & 84 \\
\hline 24 & M.M & 94 & 88 \\
\hline 25 & T.B.W & 85 & 83 \\
\hline 26 & S.K & 90 & 85 \\
\hline 27 & I.K & 91 & 82 \\
\hline 28 & I & 95 & 85 \\
\hline 29 & N.M.D & 94 & 85 \\
\hline 30 & I.M & 92 & 82 \\
\hline 31 & F.M & 85 & 85 \\
\hline 31 & E.Y & 92 & 89 \\
\hline 33 & L.M & 87 & 79 \\
\hline 34 & R.A & 82 & 78 \\
\hline 35 & D & 94 & 86 \\
\hline 36 & D.A & 93 & 84 \\
\hline 37 & N.K & 94 & 85 \\
\hline 38 & M & 94 & 85 \\
\hline
\end{tabular}

\section{Data kuesioner}

Untuk mendukung data pokok

dokumen-dokumen capaian kinerja KPI dan DP3, juga dilakukan pendistribusian angket terhadap 38 pegawai sebagai sampel objek penelitian. 
Tabel 10

Hasil Kuesioner Aktivitas menghafal dan Kinerja Pegawai

\begin{tabular}{|c|c|c|c|c|c|c|}
\hline \multicolumn{2}{|r|}{ Pertanyaan } & \multicolumn{5}{|c|}{ Jawaban } \\
\hline No & & $\begin{array}{l}\mathrm{S} \\
\mathrm{T} \\
\mathrm{S}\end{array}$ & $\mathrm{T}$ & $\begin{array}{l}\mathrm{K} \\
\mathrm{S}\end{array}$ & $\mathrm{S}$ & SS \\
\hline 1 & $\begin{array}{l}\text { Keikutsertaan } \\
\text { dalam } \\
\text { program } \\
\text { tahfizh } \\
\text { berpengaruh } \\
\text { terhadap } \\
\text { semangat } \\
\text { menyelesaikan } \\
\text { tugas dan } \\
\text { pekerjaan } \\
\text { sesuai target di } \\
\text { RSI SA }\end{array}$ & & & & 13 & 25 \\
\hline 2 & $\begin{array}{l}\text { Aktivitas } \\
\text { menghafal al- } \\
\text { Quran } \\
\text { berpengaruh }\end{array}$ & & & & 12 & 26 \\
\hline
\end{tabular}

Berdasarkan tabel diatas dapat dari 38 orang diketahui bahwa ada 13 orang yang setuju dengan pertanyaan 1 dan 25 orang sangat setuju dengan pertanyaan 1. Kemudian untuk pertanyaan kedua 12 orang setuju dan 26 orang sangat setuju. Dalam pertanyaan 3 semua orang memilih sangat setuju. Untuk pertanyaan 4 ada 8 orang memilih setuju dan 30 orang memilih sangat setuju. Lalu untuk pertanyaan 5, 4 orang

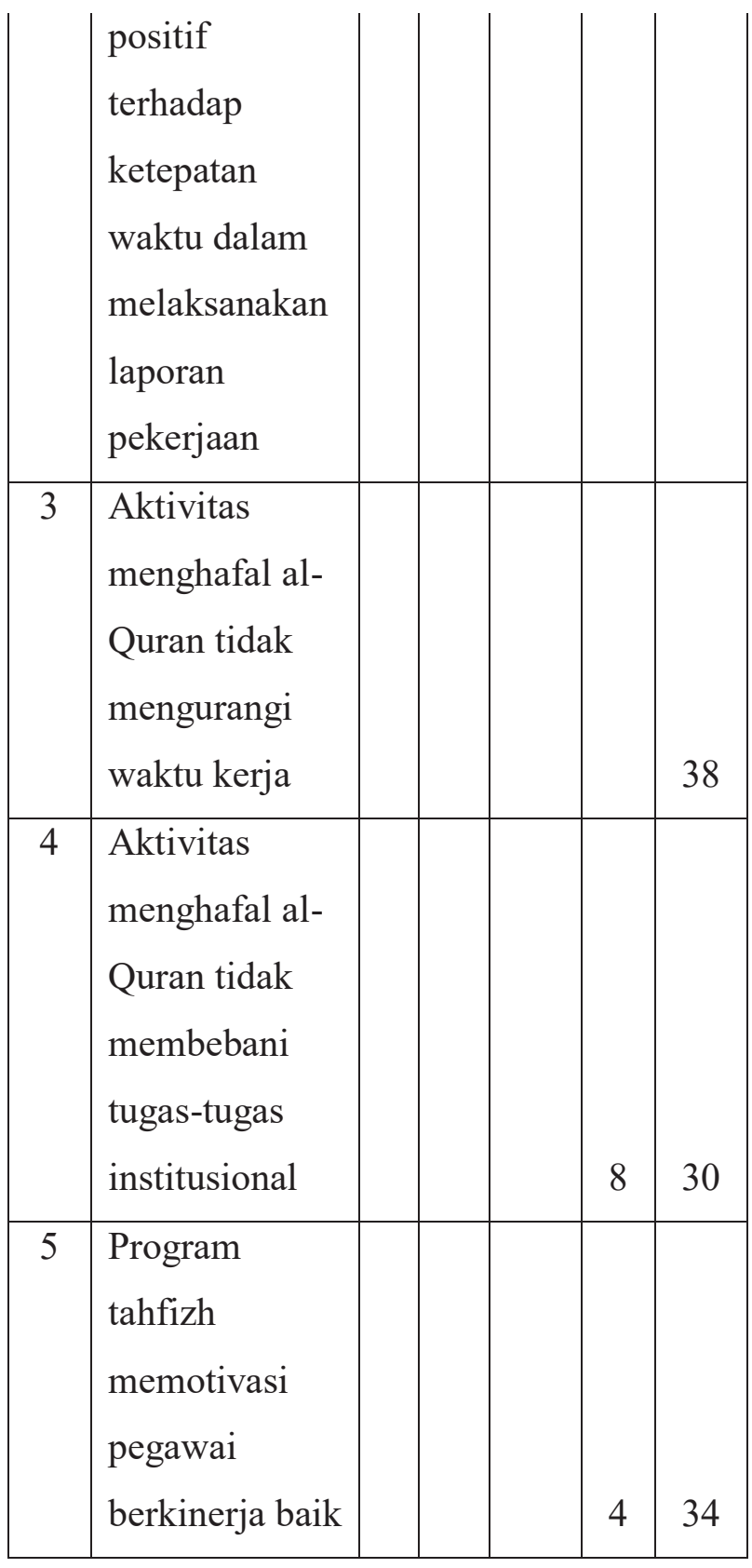

memilih setuju dan 34 orang memilih sangat setuju. Berdasarkan tabel diatas maka jika data tersebut didistribusikan dengan aturan sebagaii berikut:

- $\quad$ STS diberi skor 1

- $\quad$ TS diberi skor 2

- KS diberi skor 3

- $\mathrm{S}$ diberi skor 4

- SS diberi skor 5

Diperoleh hasil sebagai berikut 
Tabel 11

Rekapitulasi Data Kuesioner

\begin{tabular}{|c|c|c|c|c|c|c|c|}
\hline \multicolumn{2}{|r|}{ Pertanyaan } & \multicolumn{5}{|c|}{ Jawaban } & \multirow[b]{2}{*}{ Jumlah } \\
\hline No & & STS & TS & $\mathrm{KS}$ & S & SS & \\
\hline 1 & $\begin{array}{l}\text { Keikutsertaan dalam program } \\
\text { tahfizh berpengaruh terhadap } \\
\text { semangat menyelesaikan tugas dan } \\
\text { pekerjaan sesuai target di RSI SA }\end{array}$ & & & & 52 & 125 & 177 \\
\hline 2 & $\begin{array}{l}\text { Aktivitas menghafal al-Quran } \\
\text { berpengaruh positif terhadap } \\
\text { ketepatan waktu dalam } \\
\text { melaksanakan laporan pekerjaan }\end{array}$ & & & & 48 & 130 & 178 \\
\hline 3 & $\begin{array}{l}\text { Aktivitas menghafal al-Quran tidak } \\
\text { mengurangi waktu kerja }\end{array}$ & & & & & 190 & 190 \\
\hline 4 & $\begin{array}{l}\text { Aktivitas menghafal al-Quran tidak } \\
\text { membebani tugas-tugas institusional }\end{array}$ & & & & 32 & 150 & 182 \\
\hline 5 & $\begin{array}{l}\text { Program tahfizh memotivasi } \\
\text { pegawai berkinerja baik }\end{array}$ & & & & 16 & 170 & 186 \\
\hline & Total & 0 & 0 & 0 & 148 & 765 & 913 \\
\hline
\end{tabular}

Setelah dilakukan perhitungan maka jumlah skor untuk setiap pertanyaan secara berurutan adalah 177, 178, 190, 182, 186. Dapat disimpulkan bahwa pertanyaan nomor 3 merupakan pertanyaan dengan skor tertinggi, dan pertanyaan 1 merupakan pertanyaan dengan skor terendah. Kemudian jika dilihat dari tiap skor untuk skor STS, TS, KS sama dengan 0, untuk skor S sama dengan 148, dan untuk skor
SS adalah 765. Jadi dapat disimpulkan bahwa hampir 85 persen orang memilih pilihan sangan setuju.

\section{Prestasi yang Diraih}

Prestasi atau penghargaan yang diraih para pegawai RSI Sultan Agung peserta program tahfizh pada tingkat nasional Mukisi Award 2019 Event yang diselenggarakan pada 10 - 12 April 2019 adalah sebagai berikut: 
Tabel 12

Data Rekapitulasi Judul Penelitian yang Masuk

Nominasi Mukisi Award 2019 Event

\begin{tabular}{|c|c|c|c|c|c|}
\hline No & Kategori & Judul Penelitian & Unit Peneliti & $\begin{array}{c}\text { Nama } \\
\text { Peneliti }\end{array}$ & Ket. \\
\hline \multirow[t]{4}{*}{1.} & \multirow{4}{*}{$\begin{array}{l}\text { Proyek } \\
\text { Peningkata } \\
\text { n Fasilitas } \\
\text { Kesehatan } \\
\text { Syariah }\end{array}$} & $\begin{array}{l}\text { 1. } \\
\text { Pengaruh Spritual Story } \\
\text { Telling Terhadap Tingkat } \\
\text { Stres Anak Yang Dirawat Di } \\
\text { Rumah Sakit. }\end{array}$ & SDI & MAR & Nominasi \\
\hline & & $\begin{array}{l}\text { 2. Pengaruh Mendengarkan } \\
\text { Tilawah Surah Yasin } \\
\text { Terhadap Tekanan Darah }\end{array}$ & Rehab Medik & IR & \\
\hline & & $\begin{array}{l}\text { 3. } \\
\text { Efektivitas TERAJUD } \\
\text { (Terapi Sholat Tahajud) } \\
\text { Dalam Mengurangi Tingkat } \\
\text { Kecemasan Pasien } \\
\text { Kemoterapi }\end{array}$ & BPI & KK & Nominasi \\
\hline & & 4. Halal Food for Better Life & Inst Gizi & HR & \\
\hline
\end{tabular}

\begin{tabular}{|l|l|l|l|l|l|}
\hline 2. & Kualitas & 1. & Keberhasilan Pelaksanaan & & \\
& Syariah dan & Indikator Mutu Syariah : & & \\
Proyek & Membaca Basmalah Pada & KMKP & ASM & \\
Keselamata & Pemberian Obat dan & & \\
n Pasien & Tindakan. & & \\
\hline
\end{tabular}

\begin{tabular}{|l|l|l|l|l|l|}
\hline 3. & & $\begin{array}{l}\text { 2. Sistem Jaminan Halal Gizi } \\
\text { Berbasis Patient Safety }\end{array}$ & Inst Gizi & HD & Nominasi \\
\hline 4. & $\begin{array}{l}\text { Inovasi } \\
\text { Dalam } \\
\text { Proyek } \\
\text { Teknologi } \\
\text { Informasi } \\
\text { Kesehatan } \\
\text { Syariah }\end{array}$ & $\begin{array}{l}\text { SHC Mobile : Aplikasi Bantu } \\
\text { Implementasi Standar Syariah }\end{array}$ & BPI & SS & Nominasi \\
\hline
\end{tabular}




\begin{tabular}{|c|c|c|c|c|c|}
\hline 5. & $\begin{array}{l}\text { Pemasaran } \\
\text { Syariah } \\
\text { dan } \\
\text { Proyek } \\
\text { Layanan } \\
\text { Pelanggan }\end{array}$ & $\begin{array}{l}\text { Pengaruh Edukasi Kesehatan } \\
\text { RSI Sultan Agung Terhadap } \\
\text { Kesadaran Kesehatan } \\
\text { Masyarakat Kelurahan } \\
\text { Trimulyo }\end{array}$ & $\begin{array}{l}\text { Humas \& } \\
\text { Pemasaran }\end{array}$ & G & Nominasi \\
\hline \multirow[t]{2}{*}{6.} & \multirow[b]{2}{*}{$\begin{array}{l}\text { Proyek } \\
\text { Pengemba } \\
\text { ngan } \\
\text { Sumber } \\
\text { Daya } \\
\text { Insani }\end{array}$} & 1. Smart IKI IKU & SDI & MM & Nominasi \\
\hline & & $\begin{array}{l}\text { 2. Pengaruh Struktur } \\
\text { Organisasi SHC Terhadap } \\
\text { Efektifitas Implementasi } \\
\text { Standar Syariah }\end{array}$ & BPI & $\mathrm{SS}$ & Nominasi \\
\hline \multirow[t]{2}{*}{7.} & \multirow[t]{2}{*}{$\begin{array}{l}\text { Proyek } \\
\text { Manajeme } \\
\mathrm{n} \\
\text { Keuangan } \\
\text { Syariah }\end{array}$} & $\begin{array}{l}\text { 3. Penyertaan Modal } \\
\text { (Mudharabah) Adaptasi } \\
\text { Dari Model ESOP sebagai } \\
\text { alternatif penguatan modal }\end{array}$ & Keuangan & YA & \\
\hline & & $\begin{array}{l}\text { 4. Pengaruh Pemahaman } \\
\text { Akad Ijarah Terhadap } \\
\text { Risiko Komplain Pada } \\
\text { Pasien Naik Kelas }\end{array}$ & Keuangan & $\mathrm{MM}$ & \\
\hline 8. & $\begin{array}{l}\text { Dakwah } \\
\text { dan } \\
\text { Proyek } \\
\text { Tanggung } \\
\text { Jawab } \\
\text { Sosial } \\
\text { Rumah } \\
\text { Sakit }\end{array}$ & $\begin{array}{l}\text { Analisis Program Kampung } \\
\text { Harapan RSI Sultan Agung } \\
\text { Terhadap Implementasi } \\
\text { Standar Syariah }\end{array}$ & BPI & KK & Nominasi \\
\hline
\end{tabular}

\section{E. PEMBAHASAN}

Dari hasil uji statistik didapatkan bahwa data terdistribusi normal, karena nilai sig untuk semua nilai KPI lebih dari 0,05 maka 74 dapat disimpulkan bahwa data berdistribusi normal. Oleh karena itu asumsi data normalitas terpenuhi. Kemudian dilakukan uji paired sampel $\mathrm{T}$ test dan didapatkan nilai sig. Jurnal Al-Fikri Volume 3 Nomor 1 - Februari 2020 
$0,000<0,05$ yang berarti $H_{0}$ ditolak. Jadi dapat disimpulkan bahwa ada perbedaan yang signifikan antara nilai KPI sebelum (2018) dengan nilai KPI sesudah (2019).

Untuk melihat mana yang terbaik, maka dilakukan uji Paired Samples Statistics. Hasil penelitian menunjukan bahwa nilai kinerja KPI (Key Performance Indikator) pegawai RSI Sultan Agung, sebelum mengikuti program tahfizh didapati nilai keseluruhannya adalah 4.238. Jika dirataratakan dengan cara dibagi sesuai dengan jumlah pegawai sebanyak 38 responden maka nilai rata-ratanya adalah 88,34. Sedangkan nilai kinerja KPI (Key Performance Indicator) pegawai RSI Sultan Agung, setelah mengikuti program tahfizh didapati nilai keseluruhannya adalah 4.649. Jika dirata-ratakan dengan cara dibagi sesuai dengan jumlah pegawai sebanyak 38 responden maka nilai rataratanya adalah 90,29. Hasil statistic ini mengindikasikan adanya pengaruh yang signifikan aktivitas menghafal al-Quran terhadap kinerja pegawai.

Sementara hasil uji statistic pada capaian kinerja DP3 didapatkan nilai sig 0,183 $>0,05$ yang berarti $H_{0}$ diterima. Maka dapat disimpulkan bahwa tidak ada perbedaan yang signifikan antara nilai DP3 sebelum (2018) dengan nilai DP3 sesudah (2019) meskipun terdapat kenaikan nilai DP3.

$$
\text { Pada perhitungan rekapitulasi }
$$
kuesioner yang didistribusikan kepada 38 responden peserta program tahfizh Rumah Tahfizh Darus Syifa' RSI Sultan Agung menunjukkan bahwa hampir 85 persen orang memilih pilihan sangan setuju. Sehingga dapat disimpulkan adanya pengaruh aktivitas menghafal al-Quran terhadap kinerja pegawai.

Disamping tiga alat ukur untuk menilai pengaruh aktivitas menghafal, beberapa pegawai peserta program tahfizh tercatat mampu menorehkan prestasi di tingkat nasional pada lomba penelitian Mukisi Award 2019 Event. Prestasi atau penghargaan ini dapat menjadi pendukung dan penguat adanya pengaruh aktivitas menghafal al-Quran.

Dari hasil penelitian tersebut diatas, dapat disimpulkan bahwa terdapat pengaruh yang signifikan aktivitas menghafal al-Quran terhadap kinerja pegawai RSI Sultan Agung. Hal ini sesuai dengan teori yang dijelaskan pada Bab II tentang keutamaan menghafal alQuran bahwa Al-Quran mengandung keberkahan bagi siapa saja yang mengambilnya. Setiap kali kebaikan bertambah, maka keburukan akan berkurang. Setelah kebaikan bertambah, urusan-urusan kita akan diberkahi Allah sesuai dengan harapan kita. 


\section{F. PENUTUP}

Berdasarkan pembahasan yang telah dilakukan di atas maka dapat diambil kesimpulan sebagai berikut :

1. Pegawai RSI Sultan Agung yang mengikuti program pembelajaran tahfizh di Rumah Tahfizh Darus Syifa' menunjukkan kinerja yang sangat baik.

2. Aktivitas menghafal al-Quran pegawai RSI Sultan Agung yang mengikuti program pembelajaran tahfizh di Rumah Tahfizh Darus Syifa' memberikan dorongan dan motivasi untuk berkinerja lebih baik.

3. Terdapat pengaruh yang signikan aktivitas menghafal al-Quran terhadap kinerja pegawai RSI Sultan Agung yang ditunjukkan dengan adanya kenaikan nilai KPI dan DP3 setelah mengikuti program Tahfizh. 
DAFTAR PUSTAKA

Abdul Aziz, Abdur Rauf, Al-Hafidz. (2009). Anda Pun bisa Menjadi Hafidz AlQur'an, Jakarta: Markaz AlQurean.

Al-Dabisi, Muhammad, (2019). Merasakan Keberkahan Al-Quran, Hidup Lebih Sukses Lagi Bersama Kalam Allah, Jakarta: Qalam

Al-Kahel, Abduldaem. (2010). Al-Qur'an The Healing Book, Jakarta: Tarbawi Press.

Al-Majidi, A. Muqbil, (2008), Bagaimana Rasulullalah Mengajarkan AlQur'an kepada Sahabatnya, Jakarta: Darul Falah.

Ali As-Shobuny, Muhammad .(1998). Studi Ilmu Al-Qur'an, Bandung: PustakaSetia.

Al-Qur"an dan Terjemahnya. (2007).
Jakarta: Darus Sunnah.

Muhith, N. Faizin, (2012), Dahsyatnya Bacaan Al-Qur'an dan Haafalan Al-Qurean, Surakarta: Shalih.

Nur, Subhan. (2012). Energi Ilahi Tilawah, Jakarta: Penerbit Republika.

Pedak, Mustamir, Qur'anic Super Healing, Semarang: Pustaka Nuun, 2010.

Slameto, (2010), Belajar dan Faktor-Faktor yang Mempengaruhinya, Rhineka Cipta, Jakarta.

Sugiyono. (2009). Metode Penelitian Kuantitatif Kualitatif dan $R \& D$, Bandung: Al-Fabeta.

Syah, Darwan. (2010). Pengantar Statistik Pendidikan, Jakarta: GP Press.

Wibowo, (2011) Manajemen Kinerja, Jakarta: PT. Raja Grafindo Persada. 